\title{
Eco-design of technological systems in buildings
}

\author{
L. Marletta, G. Evola \& F. Sicurella \\ Department of Industrial Engineering, University of Catania, Italy
}

\begin{abstract}
In recent years the use of technological systems in buildings has considerably grown; the components are produced by industrial processes whose energetic and environmental impact is outstanding. The aim of this paper is the evaluation of the environmental impact and the energetic cost related to technological systems (heating, air conditioning, waterworks, fire-proofing, etc.). To this aim the Life Cycle Assessment approach is used; the environmental damage is assessed by means of the Eco-indicator 99 method. For every component (pipes, ducts, wires, radiators) different solutions and materials are considered, corresponding to the current technologies, in order to find out the best and less impactive solution. A case study is then considered to show the environmental benefit achievable by means of a proper design. The technical equipment of a real building is taken into account, and an "ecological" version is defined, by choosing the best solution for every component. The score of the whole apparatus in the ecological version is then compared to the one of the actual installation, showing that an outstanding reduction of the environmental impact can be obtained.
\end{abstract}

Keywords: life cycle, environmental impact, technical equipment, pipes.

\section{Introduction}

Life Cycle Assessment (LCA) is a well known methodology for the evaluation of the environmental impact associated with the production, use and disposal of a product, taking into account resources and emissions occurring throughout its life, from cradle (extraction of raw materials) to grave (disposal). There is a wide literature concerning the application of LCA to building materials, due to the importance of the sector and to the number of new constructions in previous decades. 
On the contrary, only recently has this approach been applied to heating and air conditioning systems in buildings; the interest in this field is mostly due to the rapidly increasing number of installations, as opposed to the declining building activity. Some studies can be traced back to the late eighties, concerning the energy use connected with the production of components used in heating systems, such as pipes, radiators and heat generators [1]. These analyses were only focused on the Embodied Energy, whereas no attention was paid to other impacts on the environment.

The publication of the ISO standards of the series 14040 [2], [3], [4], [5], which describe and regulate all the phases of an LCA, has led to the development of new complex evaluation methodologies for the assessment of the environmental impact, such as EPS 2000 and Eco-indicator 95, successively updated to the version 99. All of these methods consider a number of impact categories and quantify the environmental impact by means of suitable impact indicators; a final score is then obtained after a process of normalisation and weighting.

The publication of these new methods and their consequent implementation in powerful and user-friendly software packages has given new impulse to the LCA analysis of heating and air conditioning systems in buildings. Prek [6] applied Eco-indicator 95 method to compare the use of radiators, fan-coil convectors and floor heating in residential buildings. Nyman and Simonson [7] studied the environmental impact of different ventilation units, with and without energy recovery systems, in order to understand if the further environmental load due to the production of the recovery unit could be overcome by the impact avoided thanks to energy savings. Furthermore, Heikkila [8] applied EPS 2000 to evaluate the environmental impact of a conventional air handling unit, and compared it to a more efficient one, provided with a desiccant rotor to perform dehumidification.

In this paper the Eco-indicator 99 has been used to assess the impact associated with the main components of technological systems in buildings, such as pipes, ducts, radiators, gutters, drain pipes. For every component, different options were considered, according to the current practice. The aim is to guide designers to choose the best material for every component, as well as to quantify the advantages connected to the eco-design of technical equipment of buildings.

\section{Environmental impact of components: methods}

In Table 1 a list is made of the components which have been considered in this analysis. For every component different sizes are actually available, but only one has been chosen, as the results for all the other sizes may be regarded as differing for a simple scale factor.

The first step of the analysis was focused on the definition of the functional unit (FU). The standard ISO 14040 defines the functional unit as the quantity of a product system which is able to provide a certain quantified performance; according to this definition, the authors decided to consider a one-meter length as the FU for pipes, wires and ducts, while for the radiator the FU was defined as an 
element which is able to produce as much thermal power as $150 \mathrm{~W}$ when working with a temperature difference of $50^{\circ} \mathrm{C}$ between water and air.

Table 1: $\quad$ Definition of the components considered in this study.

\begin{tabular}{|c|c|c|}
\hline Component & Dimensions & Functional Unit \\
\hline Gutters & $\mathrm{r}=13 \mathrm{~cm}$ & $1 \mathrm{~m}$ \\
\hline Drain pipes & $\mathrm{D}=10 \mathrm{~cm}$ & $1 \mathrm{~m}$ \\
\hline Sewer & $\mathrm{D}=15 \mathrm{~cm}$ & $1 \mathrm{~m}$ \\
\hline Gas distribution & $\mathrm{D}=3 / 4 "$ & $1 \mathrm{~m}$ \\
\hline $\begin{array}{c}\text { Fireproof and sanitary } \\
\text { water distribution }\end{array}$ & $\mathrm{D}=2 ”$ & $1 \mathrm{~m}$ \\
\hline $\begin{array}{l}\text { Hot/cold water for } \\
\text { heating and cooling }\end{array}$ & $\mathrm{D}=1 "$ & $1 \mathrm{~m}$ \\
\hline Air ducts & $\mathrm{D}=500 \mathrm{~mm}$ & $1 \mathrm{~m}$ \\
\hline Radiators & ---- & $150 \mathrm{~W}$ \\
\hline Electric wires & $\mathrm{S}=2,5 \mathrm{~mm}^{2}$ & $1 \mathrm{~m}$ \\
\hline $\mathrm{r}=$ radius & \multicolumn{2}{|c|}{$\mathrm{S}=$ cross section } \\
\hline
\end{tabular}

Every component may be made up of different materials; all the options normally available in current design and installation practice have been considered. The definition of the amount of material used in the functional unit is derived from information supplied by producers; where no information was available, the weight of the element was computed starting from its size, and adopting the following values for density:

$\begin{array}{ll}\text { PVC : } & 1350 \mathrm{~kg} / \mathrm{m}^{3} \\ \text { HDPE: } & 970 \mathrm{~kg} / \mathrm{m}^{3} \\ \text { STEEL /IRON: } & 7800 \mathrm{~kg} / \mathrm{m}^{3} \\ \text { COPPER: } & 8900 \mathrm{~kg} / \mathrm{m}^{3}\end{array}$

Some further information should be provided concerning ducts for air distribution. Ducts are not only circular, but they can also have a rectangular shape; in this case, it is possible to define an equivalent diameter, such as the diameter of a circular duct which shows the same pressure losses per meter. If $\mathrm{D}=500 \mathrm{~mm}$ (see Table 1), the equivalent rectangular section measures $400 \mathrm{~mm} \times 500 \mathrm{~mm}$. Four different types of ducts are normally used (see Table 2).

Ducts defined in cases $\mathrm{B}$ and $\mathrm{C}$ are usually chosen when aesthetic requirements are considered more important than energy savings; case D is also known as flexible duct, as the thin layer of aluminium which forms the main frame of the duct allows the latter to be bendable. As far as electric wires are concerned, the only possible choice refers to the insulating material (PVC or Polyethylene), as copper is in any case used for the core. 
Table 2: $\quad$ Different types of ducts for air distribution.

\begin{tabular}{|c|c|c|c|}
\hline Case & Shape & Material & Insulation \\
\hline A & Rectangular & Galvanised Iron & Glass wool $(25 \mathrm{~mm})$ \\
\hline B & Circular & Stainless steel & ----- \\
\hline C & Circular & Galvanised Iron & ----- \\
\hline D & Circular & Aluminium & Glass wool $(25 \mathrm{~mm})$ \\
\hline
\end{tabular}

Once all the components have been defined, the Life Cycle Assessment may be performed. To this aim, information provided by European databases have been used for the inventory phase, concerning resources and emissions associated with the production of raw materials, as well as the processes to transform the material into the final product. The LCA has been performed by means of the Eco-indicator 99 method, implemented in the software code SimaPro 6.0. In this study the Hierarchist cultural perspective is adopted, while the weighting is carried out by means of the Average weighting set [9], [10]. Products are considered to be disposed of in landfills at the end of their life.

\section{Environmental impact of components: results}

In Table 3 and Figure 1 the main results of the analysis are shown. A first consideration can be made about the convenience in using plastic materials, such as PVC and HDPE, for pipes. Thanks to its lightness and to the lower environmental impact of the material itself [10], an HDPE one-inch pipe for heating and cooling water presents a score almost one tenth as high as for copper $(0,11 \mathrm{Pt} / \mathrm{m}$ vs. $1,27 \mathrm{Pt} / \mathrm{m})$. Copper turns out to be the less environmentally friendly material for pipes, even worse than galvanised iron, which suffers from the process of galvanisation, where zinc is used. However, copper is frequently used in heating and cooling systems because of its good properties, such as resistance to corrosion, low pressure losses and easiness of installation. HDPE is normally adopted for cold water, while it must be properly treated to be used with temperatures higher than $80^{\circ} \mathrm{C}$ (cross-linked polyethylene). $\mathrm{PVC}$ is the most suitable material for gutter, drain pipes and sewer pipes.

As far as radiators are concerned, cast iron should be avoided, while steel provides the lowest environmental impact (0,33 Pt per element producing $150 \mathrm{~W})$. Furthermore, the best solution for air distribution is represented by flexible circular ducts; galvanised rectangular ducts are slightly more impactive than circular ones $(5,1 \mathrm{Pt} / \mathrm{m}$ vs. $4,8 \mathrm{Pt} / \mathrm{m})$, but their score accounts for a layer of glass wool, so their use ensures a reduction of the heat losses which should be considered when making a choice between these two options. Circular stainless steel ducts should be avoided, as their environmental impact is five times higher than galvanised iron ducts $(15,6 \mathrm{Pt} / \mathrm{m})$; however, they are often used when no false ceiling are adopted, and aesthetic requirements are more urgent.

Finally, the use of PVC or HDPE as insulating material in electric wires is equivalent, as the most relevant contribution is due to the copper core. 
Table 3: $\quad$ Main results with reference to the Functional Unit.

\begin{tabular}{|c|c|c|c|c|}
\hline Component & Materials & $\begin{array}{l}\text { Weight } \\
\text { (kg) }\end{array}$ & $\begin{array}{l}\text { Environmental } \\
\text { Impact (Pt) }\end{array}$ & $\begin{array}{c}\text { Embodied } \\
\text { Energy (MJ) }\end{array}$ \\
\hline \multirow{3}{*}{ Gutter } & Copper & 2,99 & 4,83 & 346 \\
\hline & Galvan. Iron & 2,54 & 0,76 & 137 \\
\hline & $P V C$ & 0,44 & 0,14 & 31,6 \\
\hline \multirow{3}{*}{ Drain pipes } & Copper & 2,23 & 3,71 & 267 \\
\hline & Galvan. Iron & 1,96 & 0,55 & 106 \\
\hline & $P V C$ & 0,34 & 0,11 & 24,4 \\
\hline \multirow{3}{*}{ Sewer pipes } & Cast Iron & 23,6 & 7,24 & 1830 \\
\hline & $P V C$ & 2,36 & 0,76 & 169 \\
\hline & $H D P E$ & 2,47 & 0,9 & 208 \\
\hline \multirow{3}{*}{$\begin{array}{l}\text { Pipes for gas } \\
\text { distribution }\end{array}$} & Copper & 0,86 & 1,43 & 103 \\
\hline & Galvan. Steel & 1,18 & 0,43 & 69 \\
\hline & $H D P E$ & 0,2 & 0,07 & 16,8 \\
\hline \multirow{4}{*}{$\begin{array}{l}\text { Fireproof } \\
\text { and water } \\
\text { distribution }\end{array}$} & Steel & 4,49 & 0,74 & 198 \\
\hline & Galvan. Iron & 4,63 & 1,38 & 250 \\
\hline & $P V C$ & 1,4 & 0,45 & 100 \\
\hline & $H D P E$ & 1,05 & 0,38 & 88 \\
\hline \multirow{4}{*}{$\begin{array}{c}\text { Heating and } \\
\text { cooling } \\
\text { water }\end{array}$} & Copper & 0,76 & 1,27 & 90,6 \\
\hline & Steel & 2,20 & 0,36 & 97,3 \\
\hline & Galvan. Iron & 2,28 & 0,68 & 123 \\
\hline & $H D P E$ & 0,28 & 0,11 & 22,6 \\
\hline \multirow{4}{*}{$\begin{array}{l}\text { Ducts for air } \\
\text { distribution }\end{array}$} & Case $A$ & $17,8^{*}$ & 5,1 & 927 \\
\hline & Case B & 16 & 15,6 & 1550 \\
\hline & Case $C$ & 16 & 4,8 & 861 \\
\hline & Case D & $2,5 * *$ & 2,4 & 596 \\
\hline \multirow{3}{*}{ Radiators } & Cast Iron & 7,1 & 2,4 & 595 \\
\hline & Steel & 3,5 & 0,33 & 106 \\
\hline & Aluminium & 1,75 & 1,8 & 433 \\
\hline \multirow{2}{*}{$\begin{array}{l}\text { Electric } \\
\text { wires }\end{array}$} & $C u+P V C$ & $28,5(\mathrm{~g})^{\mathrm{o}}$ & 0,0363 & 2,63 \\
\hline & $C u+P E$ & $27(\mathrm{~g})^{00}$ & 0,0360 & 2,59 \\
\hline \multicolumn{3}{|c|}{$\begin{aligned} * & : 16,5 \mathrm{~kg} \text { steel }+1,3 \mathrm{~kg} \text { glass wool } \\
* * & : 1,9 \mathrm{~kg} \text { aluminium }+0,6 \mathrm{~kg} \text { glass wool }\end{aligned}$} & \multicolumn{2}{|c|}{$\begin{array}{c}{ }^{\circ}: 22,3 \text { g copper }+6,2 \text { g PVC } \\
\text { o о }: 22,3 \text { g copper }+4,8 \text { g HDPE }\end{array}$} \\
\hline
\end{tabular}

\section{Eco-design of technological systems: a case study}

In the previous paragraph the most environmentally friendly material was identified for every component related to technical equipment in buildings. In the following a case study is considered to understand how much an eco-design of technical equipment can depart from a conventionally designed system. 
324 Eco-Architecture: Harmonisation between Architecture and Nature
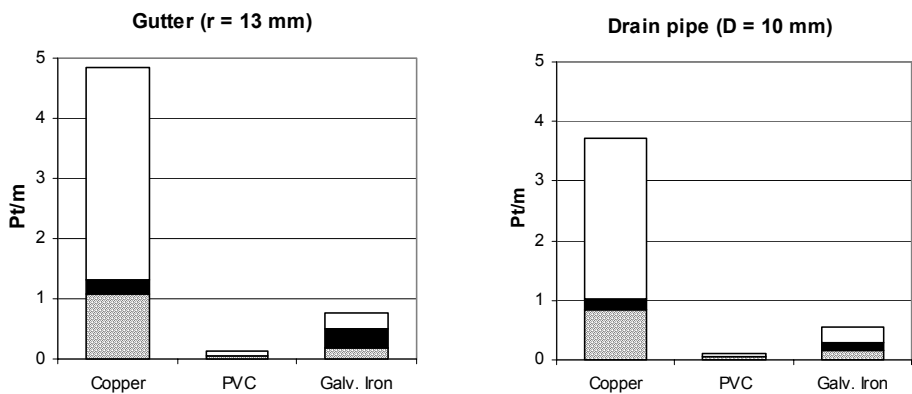

Water / Fireproof $(\mathrm{D}=\mathbf{2}$ ")
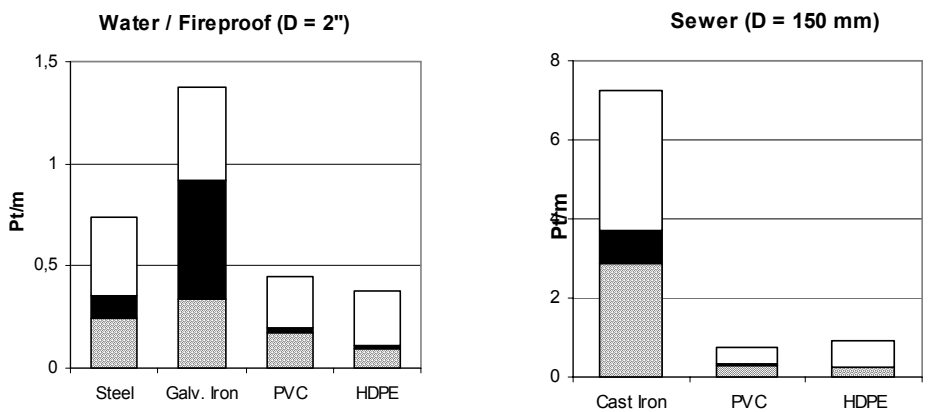

Hot water $(\mathbf{D}=1 ")$
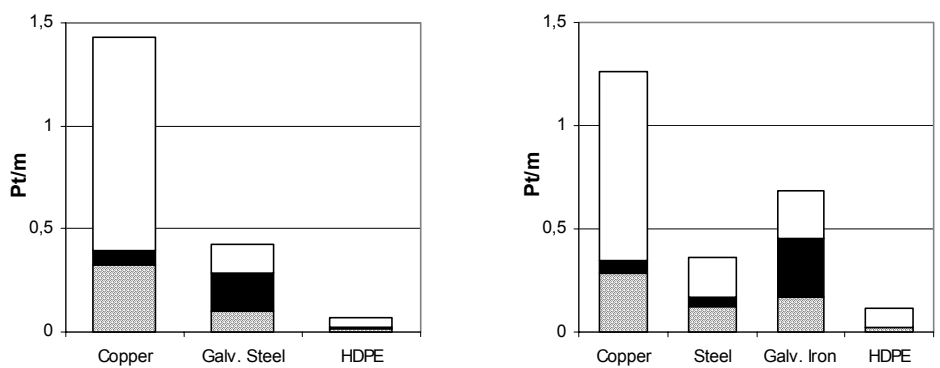

Ducts $(D=500 \mathrm{~mm})$
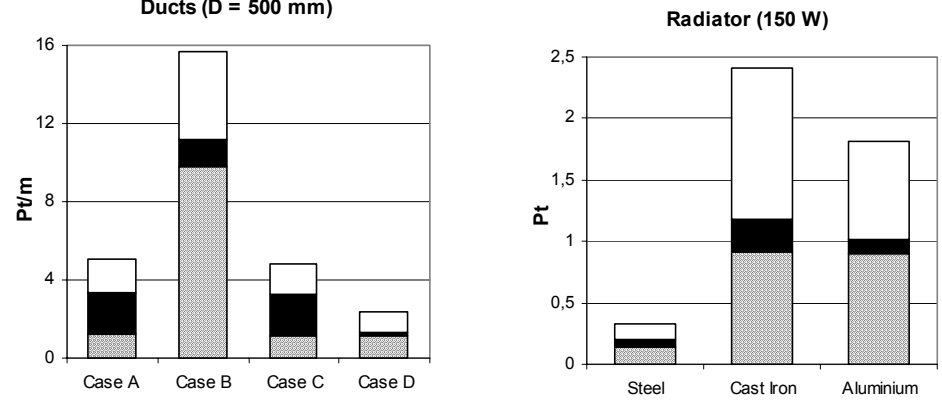

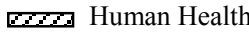

Ecosystem Quality

Resources

Figure 1: $\quad$ Eco-indicator 99 scores for the components shown in Table 1. 
To this aim the design of a school was taken into account. The school is a one-storey building, which will be built in southern Italy; the ground floor will be used for classrooms and offices, while in the basement the boiler room and some utility rooms will be placed. Each storey surface is $650 \mathrm{~m}^{2}$, and the overall volume is about $6000 \mathrm{~m}^{3}$. The ground floor is provided with a heating system, with an overall thermal load as high as $48 \mathrm{~kW}$, produced by two heat generators ( $24 \mathrm{~kW}$ each). Hot water is delivered to cast iron radiators by means of steel and copper pipes; no cooling or air conditioning system has been designed. In Table 4 the components of the technological systems are listed; the material chosen by the designer is reported, together with the one which should be used according to eco-design principles.

Table 4: $\quad$ Detailed description of the systems adopted in the case study.

\begin{tabular}{|c|c|c|c|c|}
\hline \multirow{2}{*}{ System } & \multirow{2}{*}{ Component } & \multirow{2}{*}{ Quantity } & \multicolumn{2}{|c|}{ Material } \\
\hline & & & DESIGN & ECO \\
\hline \multirow{4}{*}{ Heating } & Radiator & $315 *$ & Cast Iron & Steel \\
\hline & $\begin{array}{c}\text { Pipe for hot water } \\
\text { distribution }\end{array}$ & $470 \mathrm{~m}$ & $\begin{array}{c}\text { Copper } \\
\text { Steel }\end{array}$ & HDPE \\
\hline & Heat generator & 2 & ------- & ------ \\
\hline & $\begin{array}{l}\text { Pipe for gas } \\
\text { distribution }\end{array}$ & $20 \mathrm{~m}$ & Copper & HDPE \\
\hline $\begin{array}{c}\text { Fireproof } \\
\text { Sanitary water }\end{array}$ & Pipe & $175 \mathrm{~m}$ & Steel & HDPE \\
\hline \multirow{2}{*}{ Rain drainage } & Gutter & $77 \mathrm{~m}$ & Copper & $\mathrm{PVC}$ \\
\hline & Drain pipe & $146 \mathrm{~m}$ & Copper & PVC \\
\hline Sewer drainage & Pipe & $340 \mathrm{~m}$ & HDPE & PVC \\
\hline \multirow{2}{*}{$\begin{array}{l}\text { Electricity } \\
\text { distribution }\end{array}$} & Wire & $1060 \mathrm{~m}$ & $\begin{array}{c}\text { Copper } \\
\text { and PVC }\end{array}$ & $\begin{array}{c}\text { Copper } \\
\text { and PVC }\end{array}$ \\
\hline & $\begin{array}{l}\text { PVC pipe for } \\
\text { protection }\end{array}$ & $500 \mathrm{~m}$ & $\mathrm{PVC}$ & PVC \\
\hline
\end{tabular}

* : elements, $150 \mathrm{~W}$ each.

Table 5 shows the contribution of each system to the overall environmental impact and embodied energy, as well as the reduction achievable with an ecocompatible choice of the materials. The percentage reduction due to each system is computed as the ratio of the corresponding savings to the overall impact associated with the base-case design. The results are also shown in Figure 3 and Figure 4. The highest impact is shown by the heating system, which is responsible for $38 \%$ of the Eco-indicator score and for $46 \%$ of the embodied energy. This is mostly due to the use of cast iron radiators, while the impact of the heat generators is not relevant (see Figure 2). The latter has been quantified 
by dismantling a real heat generator and weighting its components and materials, resulting in a score as high as 23,5 $\mathrm{Pt}$ and $3150 \mathrm{MJ}$ of embodied energy for each heat generator.

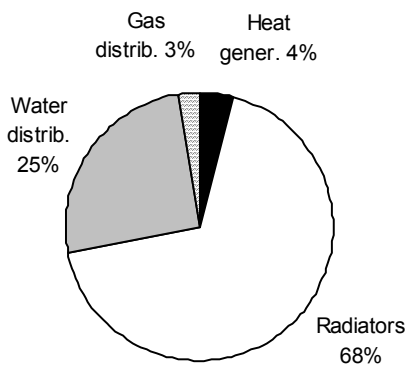

Figure 2: Heating system - percentage distribution of its environmental impact (Base-case design).

The most relevant improvements are given by means of a proper choice of heating and rain drainage systems $(31,6 \%$ and $32,8 \%$, respectively), i.e. the substitution of copper with PVC and HDPE. Minor improvements are achievable by substituting HDPE sewer pipes with PVC.

On the whole, the eco-design of the technological systems may reduce the environmental burden of the $70 \%$ if compared to the design solution, which reflects common design practice. Furthermore, the embodied energy decreases down to the $40 \%$.

Table 5: Advantages in performing eco-design of technological systems.

\begin{tabular}{|c|c|c|c|c|c|c|c|}
\hline \multicolumn{2}{|c|}{} & Heating & Firepr. & $\begin{array}{c}\text { Rain } \\
\text { drain. }\end{array}$ & $\begin{array}{c}\text { Sewer } \\
\text { drain. }\end{array}$ & Electric & TOT \\
\hline \multirow{2}{*}{$\begin{array}{c}\text { Environm. } \\
\text { Impact } \\
(\text { Pt })\end{array}$} & $\begin{array}{c}\text { Base-case } \\
\text { design }\end{array}$ & 1112 & 158 & 992 & 606 & 70 & 2938 \\
\cline { 2 - 8 } & Eco design & 184 & 90 & 29 & 509 & 70 & 882 \\
\cline { 2 - 8 } & Savings & $\mathbf{3 1 , 6} \%$ & $\mathbf{2 , 3} \%$ & $\mathbf{3 2 , 8} \%$ & $\mathbf{3 , 3} \%$ & -- & $\mathbf{7 0} \%$ \\
\hline \multirow{2}{*}{$\begin{array}{c}\text { Embodied } \\
\text { Energy } \\
\text { (MJ) }\end{array}$} & $\begin{array}{c}\text { Base-case } \\
\text { design }\end{array}$ & 224450 & 43100 & 71200 & 141000 & 7000 & 486850 \\
\cline { 2 - 8 } & Eco design & 47940 & 20900 & 6470 & 114000 & 7000 & 196410 \\
\cline { 2 - 8 } & Savings & $\mathbf{3 6 , 3} \%$ & $\mathbf{4 , 6} \%$ & $\mathbf{1 3 , 3} \%$ & $\mathbf{5 , 5} \%$ & -- & $\mathbf{5 9 , 7} \%$ \\
\hline
\end{tabular}



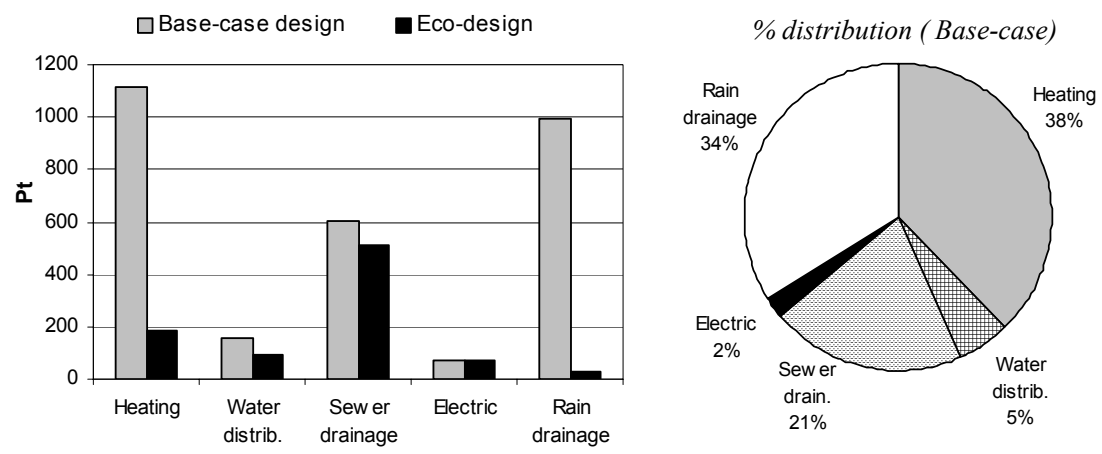

Figure 3: Environmental impact: reduction and percentage distribution.

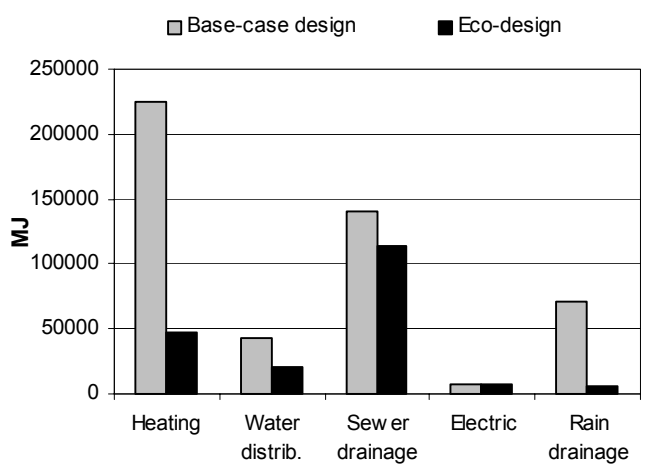

\section{$\%$ distribution (Base-case)}

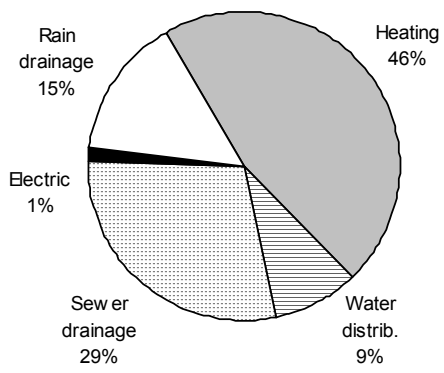

Figure 4: $\quad$ Embodied energy: reduction and percentage distribution.

\section{Conclusions}

The results presented in this study show how important may be the right choice of the materials, as far as technological systems of a building (heating, drainage, fireproof, etc.) are concerned. Relevant environmental benefits may be derived, as well as a consistent reduction of the embodied energy associated with the production, use and disposal of these kinds of systems. Of course recycling can further reduce the environmental impact; if materials are recycled at the end of their life, according to average European figures on recyclability of plastics and metals, the results shown in Figure 5 are obtained. These results are even more important if we consider that technological systems are either regularly installed in new buildings or periodically renewed in existing buildings, to be adapted to new regulations or to new standards concerning comfort and energy savings. An environmentally aware approach to systems design is therefore of primary importance; the environment can be respected not only by using more efficient systems or cleaner fuels, but also through the attentive choice of materials. 


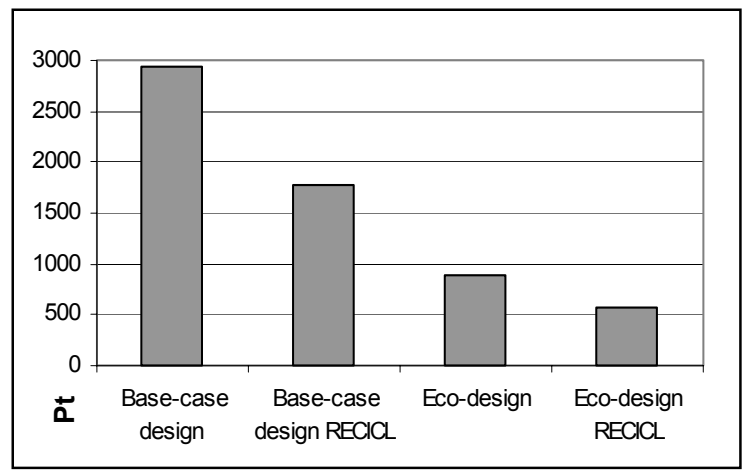

Figure 5: $\quad$ Effect of recycling on the environmental impact $(\mathrm{Pt})$.

\section{References}

[1] Baroncini C., Giacchetta G., Lucarini G., Polonara F., Manufacture and running costs for traditional and innovative heating systems, La Termotecnica, 1988.

[2] ISO 14040. Environmental management - life cycle assessment principles and framework. Geneva, Switzerland: International Standard Organization (ISO), 1997.

[3] ISO 14041. Environmental management - life cycle assessment - goal and scope definition and inventory analysis. Geneva, Switzerland: International Standard Organization (ISO), 1997.

[4] ISO 14042. Environmental management - life cycle assessment - life cycle impact assessment. Geneva, Switzerland: International Standard Organization (ISO), 1997.

[5] ISO 14043. Environmental management - life cycle assessment - life cycle interpretation. Geneva, Switzerland: International Standard Organization (ISO), 1997.

[6] Prek M., Environmental impact and life cycle assessment of heating and air conditioning systems, a simplified case study, Energy and Buildings 36 (2004), 1021-1027.

[7] Nyman M., Simonson C. J., Life cycle assessment of residential ventilation units in a cold climate, Building and Environment 40 (2005), 15-27.

[8] Heikkila K., Environmental impact assessment using a weighting method for alternative air-conditioning systems, Building and Environment 39 (2004), 1133-1140.

[9] Goedkoop M., Spriensma R. The Eco-indicator 99. A damage oriented method for life cycle assessment. Methodology report. Amersfoort, Netherlands, Prè Consultants, 2001.

[10] Marletta L., Evola G., Sicurella F., Environmental impact of materials used in technical equipments: an overview on different methods, Proc. of the $1^{\text {st }}$ Intern. Conference on Eco-Architecture. 